\title{
NPK-Liquid Fertilizer Based on Humic-Like Substances Extracted from Spent Coffee Grounds: Extraction, Preparation and Application to Maize
}

\author{
Mahmoud Kamh. ${ }^{* 1}$, Ramzy M. R. Hedia ${ }^{1}$
}

\begin{abstract}
Reuse of agricultural waste materials is a smart solution for reducing their environmental impacts and increase economic value. Spent coffee grounds (SCG) is worldwide generated in tremendous amounts. The objectives of this study were to optimize a method to extract humic-like substances (HLS) from SCG using KOH extractant, prepare a liquid organic-mineral fertilizer enriched with $N$ and $P$ in addition to $K$, and to evaluate this fertilizer on growing maize (Zea mays $\mathrm{L}$.). HLS extracted from SCG increased with KOH concentration up to $3 N$ and with extraction ratio up to $1: 10$ at room temperature. Increasing the temperature to 50 and $80{ }^{\circ} \mathrm{C}$ and contact time up to $3 \mathrm{~h}$, significantly enhanced HLS recovery. Therefore, the optimum conditions for maximum HLS extraction were; $2 \mathrm{~N}$ KOH, SCG-to-extractant ratio of $1: 10,3 \mathrm{~h}$ of contact time, and $80{ }^{\circ} \mathrm{C}$. Adjusting the $\mathrm{pH}$ of the alkaline K-HLS supernatant to $\mathrm{pH} 6$ was achieved using a mixture of $\mathrm{HNO}_{3}$ and $\mathrm{H}_{3} \mathrm{PO}_{4}$. The prepared NPK mineral-organic fertilizer (NPK-HLS) was dark brown containing 2.0/5.8/8.6 as $\mathrm{N} / \mathrm{P}_{2} \mathrm{O}_{5} / \mathrm{K}_{2} \mathrm{O}$ and $5.1 \% \mathrm{w} / \mathrm{v}$ HLS.
\end{abstract}

The produced fertilizer was evaluated for its effect on maize plants grown in a calcareous soil low in available nutrient using a CRBD pot experiment. Two application rates of NPK-HLS (NPK-HLS1 and NPK-HLS2) based on $P$ rates, 125 and $250 \mathrm{mg} \mathrm{P}$ pot $^{-1}$, with and without a basic fertilizer (BF) were applied. Both NPK-HLS1 and NPKHLS2 rates significantly increased shoot dry matter, NPK uptake and availability in soil compared to the control, but did not significantly affect root dry matter. Increasing the application rate to NPK-HLS2 did not further increase dry matter or NPK uptake. No significant effect was found for BF for all measured variables. Results of this study showed that the extraction of HLS from SCG and its incorporation into a liquid fertilizer could be an alternative solution to the reuse of SCG.

Key words: Spent coffee grounds, alkali extracts, mineral-organic fertilizers, maize growth, NPK uptake.

\section{INTRODUCTION}

World coffee production recorded about 9.39 million tons for the year 2015/16 and it is expected to increase in the future (USDA, 2016). Large amounts of residual materials known as spent coffee grounds (SCG) remained after brewing coffee with hot water or steam. Production of $1 \mathrm{~kg}$ instant coffee generates $4 \mathrm{~kg}$ of SCG (Punnet, 1958) with total amount of 6 million tons of SCG worldwide each year (Mussatto et al., 2011).
Presently, some manufacturers of instant coffee use SCG as a fuel to generate steam from industrial boilers because of its high calorific value or otherwise, highly moist SCG is disposed to landfills (Silva et al., 1998; Chiyanzy et al., 2014). The disposal of SCG represents a potential hazard to the environment and requires waste management plans compatible with the regulations of each country (Campos-Vega et al., 2015). If SCG can be reused or recycled, this will increase its value and will minimize subsequent environmental problems.

Ballesteros et al., (2014) found that SCG is a sugarrich lignocellulosic material with high levels of insoluble, soluble, and total dietary fibers. It has also functional properties including water- and oil-holding capacity, emulsion activity and stability. A low-cost activated carbon or biochar produced from SCG through pyrolysis was used in the adsorption some heavy metal ions (Jutakridsada et al., 2015), phenols (Alves et al. 2015) from aqueous solutions, removal of acid and basic dyes (Namanea et al., 2005) and colors (Chinmai, et al., 2014) from wastewater and production of high performance electric double-layer capacitors (Kamikuri et al., 2014).

SCG cannot be considered as a simple vegetable compound (Cruz et al., 2012). Its direct application to the soil reduced the growth of broccoli, leek, radish, viola and sunflower plants regardless of soil type and fertilizer additions (Hardgrove and Livesley, 2016) due to some phytotoxic effects of SCG; especially caffeine. However, its application at low rates $(2.5$ to $10 \% \mathrm{v} / \mathrm{v})$ in a greenhouse experiment with lettuce (Lactuca sativa L.) improved the biomass, chlorophylls, $\beta$-carotene, and lutein levels compared to the control. Nevertheless, the organic nitrogen contents of plants were decreased (Cruz et al., 2012). Treating a calcareous subsoil ( $\mathrm{pH}=$ 9.3) with different rates of composted SCG, containing $40 \mathrm{mg} \mathrm{Fe} \mathrm{kg}{ }^{-1}$ dry weight, improved soil $\mathrm{Fe}$ phytoavailability compared with the soil treated with only ferrous sulfate (Morikawa and Saigusa, 2008). This might due to its content of organic compounds such as fatty acids, amino acids, polyphenols, and polysaccharides (Campos-Vega et al., 2015).

Organic-mineral fertilizers, containing humic substances (HS) have been used in agriculture to supply plants with their nutritional needs and to improve soil

${ }^{1}$ Soil and Water Sciences Department, Faculty of Agriculture, Alexandria University, Egypt

"Corresponding author: mahmoud.kamh@alexu.edu.eg

Received May 20, 2018, Accepted June 12, 2018 
properties as well (Knany et al., 2009). HS can be extracted from soil, leonardite, compost, peat, and composted plant residues using alkali extractants such as $\mathrm{NaOH}, \mathrm{NaOH}+\mathrm{Na}_{2} \mathrm{P}_{2} \mathrm{O}_{7}$, or $\mathrm{KOH}$ (Hayes and Swift, 1978; Schnitzer, 1982; Huculak-Moczka et al., 2018). The use of $\mathrm{NaOH}$, despite its low cost, has undesirable effects on soils and plants when included in a fertilizer especially in salt affected soils. Instead of $\mathrm{NaOH}$, potassium hydroxide $(\mathrm{KOH})$ was used to extract $\mathrm{HS}$ from organic materials (Valdrighi et al., 1996, SuarezEstrella 2008, Hoculak-Maczka et al., 2018). It is preferred not only because potassium is an essential nutrient for plants, but also because $\mathrm{KOH}$ proved to be the most efficient among other alkali agents in extraction of HS from the HS source materials (Gracia et al., 1993; Stevenson, 1994; Asing et al., 2009). It was also efficient in extracting bioactive substances including natural growth hormones and biostimulants (Anon, 2004). As suggested by Asing et al. (2009), the smaller ionic size of $\mathrm{K}^{+}$causes intra- and intermolecular charges of $\mathrm{HS}$ to expand more than with $\mathrm{Na}^{+}$. The objectives of this study, therefore, were to: optimize a procedure to extract humic-like substances (HLS) from spent coffee grounds, prepare a liquid organic-mineral fertilizer based on the extractable HLS, and evaluate the effect of the prepared fertilizer on maize (Zea mays L.) growth and NPK uptake.

\section{MATERIALS AND METHODS}

\section{1- Spent Coffee Grounds (SCG):}

Coffee ground, finely ground Brazilian brand $(<0.5$ $\mathrm{mm}$ ), was obtained from the local market in Alexandria, Egypt. The coffee ground was brewed according to the tradition Arabian recipe. One kilogram of coffee grounds was cooked in $3.5 \mathrm{~L}$ of tap water. The brew was discarded and the solid residual spent coffee grounds (SCG) was freely drained, then air dried. The air-dried SCG was gently segregated using a porcelain crucible and packed in a plastic container for later use.

\section{2- Extraction of HLS from SCG:}

To optimize the extraction procedure of alkali extractable humic-like substances (HLS) using $\mathrm{KOH}$ from SCG, the effects of $\mathrm{KOH}$ concentration, temperature, SCG-to-extractant ratio, and contact time were investigated. Firstly, $5 \mathrm{~g}$ of SCG was shaken with $0,1,2,3,4$, and $5 \mathrm{~N}$ of $\mathrm{KOH}$ at three SCG-to-extractant ratios $(1: 5,1: 10$, and 1:20) in polypropylene conical flasks. The shaking was carried out at $120 \mathrm{rpm}$ on a horizontal shaker for $24 \mathrm{~h}$ at room temperature $(\approx 25$ $\left.{ }^{\circ} \mathrm{C}\right)$. The suspension was then centrifuged at $1000 \mathrm{rpm}$ for $5 \mathrm{~min}$ to obtain the supernatant. Organic carbon (mg $\mathrm{OC} \mathrm{g}^{-1} \mathrm{SCG}$ ) in the supernatant was determined by the wet oxidation procedure (Bremner and Jenkinson, 1960) as an indicator for the HLS percentage (HLS \%). KOH concentration and the ratio of SCG-to-extractant which gave the significantly highest HLS \% were assigned ( $\mathrm{C}_{\mathrm{KOHmax}}$ and $\mathrm{R}_{\max }$, respectively).

Secondly, the effect of temperature $(25,50$, and 80 ${ }^{\circ} \mathrm{C}$ ) on the HLS \% was investigated using the assigned $\mathrm{C}_{\mathrm{KOH} \max }$ and $\mathrm{R}_{\max }$. SCG-extractant suspensions were heated in an electric oven to 50 and $80{ }^{\circ} \mathrm{C}$, periodically shaken for $24 \mathrm{~h}$, the supernatant was obtained and OC was determined as previously described. The optimum temperature that gave the significantly highest HLS \% was assigned $\left(\mathrm{TMP}_{\max }\right)$.

Finally, the effect of contact time between SCG and the $\mathrm{KOH}$ extractant was tested. Equilibration of $5 \mathrm{~g}$ SCG with KOH extractant was conducted for 1, 2, 3, 4, 5, 12 and $24 \mathrm{~h}$ under $\mathrm{C}_{\mathrm{KOH} \max }, \mathrm{R}_{\max }$, and $\mathrm{TMP}_{\max }$ combination assigned from the previous two experiments and OC was determined in the supernatant. The contact time which gave the significantly highest HLS $\%$ was identified $\left(\mathrm{T}_{\max }\right)$.

\section{3- Preparation of the liquid fertilizer:}

The most efficient extraction procedure obtained from the preceding experiment was used to extract the HLS from SCG for fertilizer preparation. The obtained supernatant was enriched with $\mathrm{N}$ and $\mathrm{P}$ by adjusting the $\mathrm{pH}$ of the alkaline K-HLS supernatant at 6.0 using $8.0 \mathrm{~N}$ $\mathrm{HNO}_{3}$ and $8.0 \mathrm{~N} \mathrm{H}_{3} \mathrm{PO}_{4}$. The resultant fertilizer is a mineral-organic solution containing $\mathrm{N}, \mathrm{P}$ and $\mathrm{K}$ nutrients and the HLS extracted from SCG (denoted herein as NPK-HLS).

\section{4- Application of the prepared NPK-HLS to maize plants:}

A pot experiment was conducted in a greenhouse to test the effect of NPK-HLS on N, P, and K phytoavailability and growth of maize plant (Zea mays L.). A soil sample (Typic calciorthids, sandy clay loam, $\mathrm{EC}=1.5 \mathrm{dS} \mathrm{m}{ }^{-1}, \mathrm{pH}=8.12, \mathrm{CaCO}_{3}=14 \%$ ) was collected from West Nubaria, Behira Governorate, Egypt. The soil sample was air-dried, ground and sieved to pass $<2 \mathrm{~mm}$ sieve. PVC pots $(25 \mathrm{~cm}$ diameter $\mathrm{x} 15$ $\mathrm{cm}$ height) were packed with $3.0 \mathrm{~kg}$ soil. Six maize seeds were planted in each pot and tap water $(\mathrm{EC}=0.4$ $\mathrm{dSm}^{-1}$ ) was used for irrigation to maintain the moisture content of the soil at about $60 \%$ of its water holding capacity. A week after sowing (WAS) the number of seedlings was thinned to 3 plants pot ${ }^{-1}$. Two WAS, the prepared liquid fertilizer (NPK-HLS) was applied with irrigation water based on $\mathrm{P}$ at three application rates $\left(0.0,125\right.$, and $250 \mathrm{mg} \mathrm{P}$ pot $\left.^{-1}\right)$. These treatments were tested with and without a pre-planting basic fertilizer (BF) dose (50 mg P pot ${ }^{-1}$ as superphosphate and $50 \mathrm{mg}$ $\mathrm{N}$ pot ${ }^{-1}$ as $\mathrm{NH}_{4} \mathrm{NO}_{3}$ ). NPK-HLS fertilizer rates were split to be applied twice a week for further 4 weeks. A control treatment which received neither BF nor liquid 
fertilizers was included. The treatments were applied according to the completely randomized block statistical design with triplicates for each treatment.

Maize plants (shoot and roots) were harvested 6 WAS. Fresh and dry (oven-dried at $72{ }^{\circ} \mathrm{C}$ ) matter of both shoot and roots were measured. Plant dry matter was ground, and subsamples were dry-ashed at $500{ }^{\circ} \mathrm{C}$ then dissolved in $6 \mathrm{~N} \mathrm{HCl}$. $\mathrm{P}$ and $\mathrm{K}$ concentrations were determined in the aliquots using the vanado-molybdate method and flame photometer, respectively (Chapman and Pratt, 1961). Representative soil samples were collected from each pot for the determination of available soil $\mathrm{P}$ and $\mathrm{K}$. Available soil $\mathrm{P}$ was extracted using $0.5 \mathrm{M} \mathrm{NaHCO}_{3}(\mathrm{pH} 8.5$ ) according to (Olsen and Sommers, 1982) and $\mathrm{P}$ concentration was determined photometrically using the ammonium molybdate procedure (Murphy and Riely, 1962). Available soil K was extracted using $1.0 \mathrm{~N} \quad \mathrm{NH}_{4} \mathrm{AOc}$ according to (Knudsen et al., 1982) and $\mathrm{K}$ concentration was determined using a flame photometer.

Statistical analysis of the data obtained was carried out using the CoStat software package (CoHort, 2004). Comparisons between means were tested using the least square difference technique of Student-Newman-Keuls at $5 \%$ significance level $\left(\operatorname{LDS}_{.05}\right)$.

\section{RERSULTS AND DISCUSSION}

\section{Optimum conditions of extracting HLS from SCG}

\section{Concentration of KOH and SCG-Extractant ratio:}

Figure (1) shows the influences of $\mathrm{KOH}$ concentration and the SCG-to-extractant ratio at room temperature on the HLS \% (g HLS/100 g SCG). Data revealed that using the alkaline solution of $\mathrm{KOH}$ resulted in a substantial increase in HLS \% compared to the extraction with distilled water $(0.0 N \mathrm{KOH})$. Average HLS \% increased from $2.86 \%$ for distilled water to $24.15 \%$ for $1.0 \mathrm{~N} \mathrm{KOH}$ extractant LSD $_{.05}=$ 1.65). Increasing $\mathrm{KOH}$ concentration from 1 to $2 \mathrm{~N}$ increased the activity of $\mathrm{K}^{+}$to react with acidic functional groups on SCG that led to a significant increase of HLS \% to $27.17 \%$ (Fig. 1). Further increase in the concentration (up to $5.0 \mathrm{~N}$ ) seemed to have an oxidative disruption effect on organic molecules (Stevenson, 1982) that led to insignificant increase of HLS yield. The optimum concentration of $\mathrm{KOH}$ extractant seemed to depend on the HS source material; $0.25 \mathrm{~N} \mathrm{KOH}$ for coal and compost (Asing et al., 2009), $3.5 \mathrm{~N}$ for leaching HS from leonardite (Canieren et al., 2017), and 0.5 $N$ or lower for peat (Saito and Seckler, 2014).

For all $\mathrm{KOH}$ concentrations, SCG-to-extractant ratio significantly affected the HLS \% (Fig. 1). Increasing the

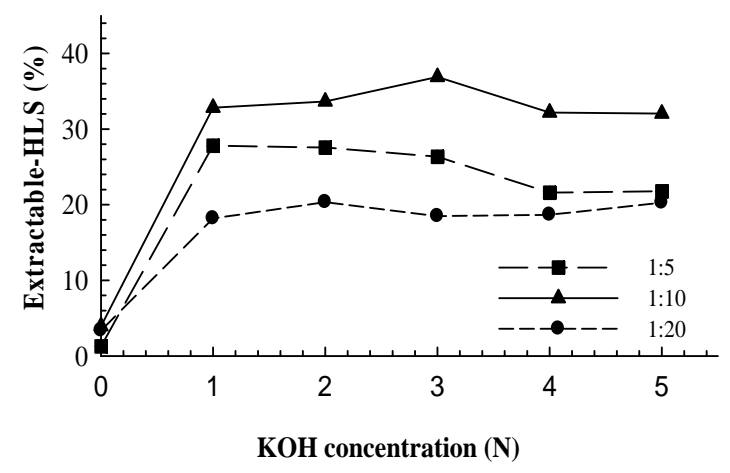

Fig. 1. Humic-like substances (HLS, \%w/w) extracted from SCG using different KOH concentrations and SCG-to-KOH extractant ratios

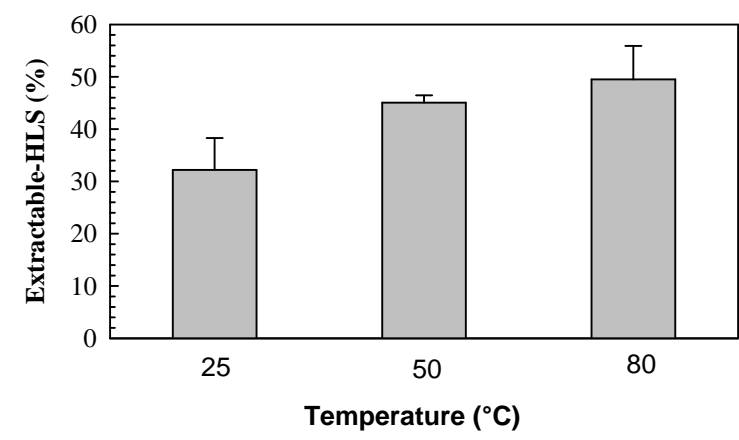

Fig. 2. Humic-like substances (HLS, \% w/w) extracted from SCG using 2.0 N KOH and 1:10 SCG-to-KOH extractant ratio at different temperatures

SCG-to-extractant ratio from 1:5 to $1: 10$ significantly increased the HLS \% from $16.67 \%$ to $28.59 \%$, respectively $\left(\mathrm{LSD}_{.05}=2.55\right)$. However, widening the ratio to 1:20 significantly reduced the HLS yield to $21.06 \%$ (Fig. 1), due probably to the excessive dilution of the extracted HLS. The ratio 1:10 was preferred by many authors (Swift, 1996; Anon, 2004; Suarez-Estrella et al., 2008; Asing et al., 2009) for the recovery of HS from varies organic materials. In the present work, the extractant concentration of $2.0 \mathrm{~N} \mathrm{KOH}\left(\mathrm{C}_{\mathrm{KOH} \max }\right)$ and the SCG-to-extractant ratio $1: 10\left(\mathrm{R}_{\max }\right)$ were considered the optimum conditions for obtaining the significantly highest HLS \% from SCG at room temperature.

\section{Temperature:}

Data of the effect of temperature on HLS \% using $2.0 N \mathrm{KOH}$ and 1:10 SCG-to-KOH extractant ratio $\left(\mathrm{C}_{\mathrm{KOHmax}}\right.$ and $\mathrm{R}_{\max }$, respectively) are shown in Fig. 2. Since rate of chemical reactions is proportionally increased with temperature, extraction of HLS from SCG was significantly increased by increasing the temperature from $32.11 \%$ at $25{ }^{\circ} \mathrm{C}$ (ambient 
temperature) to $44.21 \%$ and $50.05 \%$ at 50 and $80{ }^{\circ} \mathrm{C}$, respectively. Increasing the temperature seems to increase the rate of the hydrolysis reaction and enhanced the efficiency of HLS extraction using $\mathrm{KOH}$. Further increase in temperature above $80{ }^{\circ} \mathrm{C}$ was avoided to prevent destruction of the HLS molecular structures at higher temperatures (Yamamoto et al., 1994; Canieren et al., 2017). The temperature of $80{ }^{\circ} \mathrm{C}$ was assigned to be the optimum temperature for maximum HLS \% (TMP $\left.\mathrm{Tax}_{\max }\right)$.

\section{Contact time:}

Contact time (Fig. 3) had pronounced effect on HLS yield under $\mathrm{C}_{\mathrm{KOH} \max }, \mathrm{R}_{\max }$, and $\mathrm{TMP}_{\max }$. At the beginning of the extraction process, $\mathrm{KOH}$ removed the more easily solubilized organic fractions of SCG (Asing et al., 2009). Increasing the contact time enabled $\mathrm{KOH}$ to attack the more recalcitrant fractions. In the present work, increasing the contact time from 1 to 2 and $3 \mathrm{~h}$ significantly increased HLS \% from 44.12 to 47.62 and $51.11 \%$, respectively $\left(\operatorname{LSD}_{.05}=2.07\right)$. On the other hand, further increase of the contact time (up to $24 \mathrm{~h}$ ) had an insignificant effect on HLS \%, indicating that the HLS reservoir was exhausted. Stevenson (1994) and Asing et al. (2009) suggested that increasing HS recovery using caustic alkali from soils and leonardite with extraction time can be attributed to the slow de-polymerization of molecules of high molecular weights. Accordingly, the contact time of $3 \mathrm{~h}$ was selected as the optimum equilibrium time for maximum HLS \% $\left(\mathrm{T}_{\max }\right)$.

\section{NPK-HLS Fertilizer:}

The assigned optimum conditions $\left(\mathrm{C}_{\mathrm{KOH} \max }, \mathrm{R}_{\max }\right.$, $\mathrm{TMP}_{\max }$, and $\mathrm{T}_{\max }$ ) for HLS extraction from SCG were then applied to obtain an adequate amount of the HLS supernatant. After $\mathrm{pH}$ adjustment at 6.0 (using $\mathrm{HNO}_{3}$ and $\mathrm{H}_{3} \mathrm{PO}_{4}$ ), the NPK-enriched HLS supernatant was

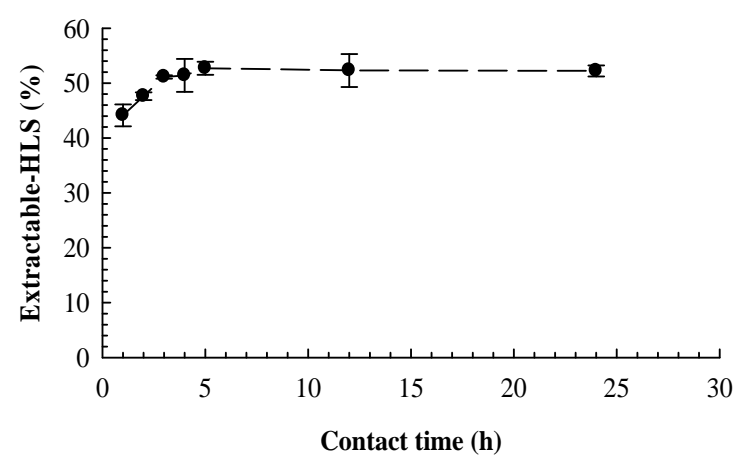

Fig. 3. Humic-like substances (HLS, \% w/w) extracted from SCG using 2.0N KOH, 1:10 SCG-KOH extractant ratio at $80^{\circ} \mathrm{C}$ at different contact times
Table 1.Main properties of the NPK-HLS liquid fertilizers

\begin{tabular}{ll}
\hline \multicolumn{1}{c}{ Properties } & Values \\
\hline $\mathrm{pH}$ & 6.0 \\
$\mathrm{Color}$ & Dark brown \\
$\mathrm{S} . \mathrm{G}^{*}$ & 1.09 \\
$\mathrm{HLS}, \%(\mathrm{w} / \mathrm{v})$ & 5.1 \\
Nutrients content, \% & \\
$\mathrm{N}$ & 2.0 \\
$\mathrm{P}_{2} \mathrm{O}_{5}$ & 5.8 \\
$\mathrm{~K}_{2} \mathrm{O}$ & 8.6 \\
\hline
\end{tabular}

S.G. Specific Gravity $\left(\mathrm{g} \mathrm{g}^{-1}\right)$

considered as a liquid fertilizer (NPK-HLS). The main properties of the NPK-HLS fertilizer are listed in Table 1. NPK-HLS is a liquid organic-mineral fertilizer having a dark brown color. It has $\mathrm{N} / \mathrm{P}_{2} \mathrm{O}_{5} / \mathrm{K}_{2} \mathrm{O}$ contents of $2 / 5.8 / 8.6 \%$ and $5.1 \%(\mathrm{w} / \mathrm{v})$ HLS. The application of NPK-HLS fertilizer may have benefits of plant nutrition and improvement of soil condition for its NPK and HLS contents, respectively. The fertilizer can be applied, after suitable dilution, either to the cultivated soil with irrigation water or as a foliar application.

\section{Effect of NPK-HLS Application on Maize Growth and NPK Uptake:}

Direct application of SCG to the soil especially in high rates resulted in negative effect on plant growth (Cruz et al., 2012; Hardgrove and Livesley, 2016). Caffeine and chlorogenic acids in SCG might be toxic to soil microorganisms and plants. Extraction of HLS from SCG and producing a liquid fertilizer which can be applied at low rates may overcome such toxic effects. Also, Alkali extracts of SCG were found to contain polyphenoles, lignin, and many polysaccharides such as galactose, arabinose, glucose and mannose (Pujol et al., 2013; Ballesteros et al., 2015), and it had antioxidant properties that can be utilized as a good source of hydrophilic bioactive compounds (Bravo et al., 2012; Acevedo et al., 2013). The application of such compounds through the NPK-HLS fertilizer to the soil could have stimulation effect on root growth and activity of plants thus enhanced their nutrient uptake and plant growth.

The prepared fertilizer was tested for its effect on maize growth and NPK uptake in a pot experiment. Average maize shoot and root dry matter $\left(\mathrm{g} p o t^{-1}\right)$ and their statistical significance and $\mathrm{LSD}_{.05}$ values are listed in Tables 2 and 4, respectively. Statistical analysis revealed that there was high significant effect of NPKHLS application on increasing shoot dry matter compared to the untreated soil (Table 4). Application of NPK-HLS resulted in an increase of $157 \%$ in shoot dry matter compared to the untreated soil. Increasing the 
application rate from NPK-HLS1 (125 mg $\left.\mathrm{P}_{\text {pot }}^{-1}\right)$ to NPK-HLS2 (250 mg P pot $\left.{ }^{-1}\right)$ did not significantly increase the shoot dry matter $\left(\mathrm{LSD}_{.05}=0.37\right)$. However, no significant differences were found between means of root dry matter due to the application of NPK-HLS compared to the untreated soil $\left(0.85 \mathrm{~g} \mathrm{pot}^{-1}\right)$. In addition, insignificant effects were found due to application of the basic fertilizer (BF) before planting on shoot and root dry matter (Table 4).

Mean values of $\mathrm{N}, \mathrm{P}$ and $\mathrm{K}$ uptake $\left(\mathrm{mg} \mathrm{pot}^{-1}\right)$ are listed in Table 3. It was observed that N, P and $\mathrm{K}$ uptake by maize were significantly influenced by the application of NPK-HLS (Table 4). Mean values of N uptake (Table 3) were increased from 35.35 to 74.39 and $75.30 \mathrm{mg} \operatorname{pot}^{-1}$ for NPK-HLS1 and NPK-HLS2, respectively $\left(\mathrm{LSD}_{.05}=\right.$ 9.76). Mean $\mathrm{P}$ uptake was increased to 16.75 and $16.86 \mathrm{mg} \mathrm{pot}^{-1}$ for NPK-HLS1 and NPK-HLS2, respectively, compared to the untreated soil $\left(9.16 \mathrm{mg} \mathrm{pot}^{-1}\right)$. Similarly, mean values of $\mathrm{K}$ uptake were significantly increased to 120.09 and $126.57 \mathrm{mg} \operatorname{pot}^{-1}$ for NPK-HLS1 and NPK-HLS2, respectively, compared the untreated soil (73.96 $\mathrm{mg} \mathrm{pot}^{-}$
${ }^{1}$ ). The increase in the uptake of $\mathrm{N}, \mathrm{P}$ and $\mathrm{K}$ by maize plants in the tested soil might also due to the improved solubility and availability of nutrients in the soil by the chelation effect of humic substances included in the tested NPK-HLS fertilizer (Piccolo, 1996; Ghabbour and Davies, 2005; Campos-Vega et al., 2015). However, this effect cannot be exclusively explained from the present work and needs more investigations. The soil used in this study was low in available $\mathrm{N}, \mathrm{K}$ and $\mathrm{P}$. Measured $\mathrm{K}$ and $\mathrm{P}$ after harvest of maize were 82.2 and $5.4 \mathrm{mg} \mathrm{kg}^{-1}$ soil, respectively. Available $\mathrm{N}, \mathrm{P}$, and $\mathrm{K}$ were significantly higher due to the application of BF and/or NPK-HLS compared to the control (data not shown). Application of NPK-HLS1 increased soil-K by $328 \%$ and soil-P by $548 \%$ compared to the control. Increasing the NPK-HLS application rate from NPKHLS1 to NPK-HLS2 did not significantly affect neither $\mathrm{N}$, P or $\mathrm{K}$ uptake (Table 3) nor residual $\mathrm{K}$ and $\mathrm{P}$ available in soil (not shown). Although application of $\mathrm{BF}$ significantly increased mean $\mathrm{N}$ uptake from 57.01 to $66.34 \mathrm{mg} \mathrm{pot}^{-1}\left(\mathrm{LSD}_{.05}=7.97\right)$,

Table 2. Mean values of shoot and root dry matter $\left(\mathrm{g} \mathrm{pot}^{-1}\right)$ of maize (Zea mays L.) for NPK-HLS application rates with and without basic fertilizer

\begin{tabular}{ccccccc}
\hline \multirow{2}{*}{ Treatments } & \multicolumn{3}{c}{ Shoot } & \multicolumn{3}{c}{ Root } \\
\cline { 2 - 7 } & Without BF $^{*}$ & With BF & Mean & Without BF & With BF & Mean \\
\hline Control & 1.60 & 1.85 & $1.72 \mathrm{~b}$ & 0.86 & 0.84 & $0.85 \mathrm{a}$ \\
NPK-HLS1 & 2.71 & 2.70 & $2.70 \mathrm{a}$ & 1.08 & 1.01 & $1.04 \mathrm{a}$ \\
NPK- HLS2 & 2.65 & 2.75 & $2.71 \mathrm{a}$ & 1.17 & 0.93 & $1.05 \mathrm{a}$ \\
Mean & $2.32 \mathrm{a}$ & $2.43 \mathrm{a}$ & & $1.04 \mathrm{a}$ & $0.92 \mathrm{a}$ & \\
\hline
\end{tabular}

${ }^{*}$ BF: basic fertilizer

${ }^{+}$Means with the same letter are not significantly different

Table 3. Mean values of N, P and K uptake $\left(\mathrm{mg} \mathrm{pot}^{-1}\right)$ for NPK-HLS application rates with and without basic fertilizer

\begin{tabular}{cccccccccc}
\hline & \multicolumn{3}{c}{ N uptake } & \multicolumn{3}{c}{ P uptake } & \multicolumn{3}{c}{ K uptake } \\
\cline { 2 - 10 } Treatments & $\begin{array}{c}\text { Without } \\
\text { BF }^{*}\end{array}$ & $\begin{array}{c}\text { With } \\
\text { BF }\end{array}$ & \multirow{2}{*}{ Mean } & $\begin{array}{c}\text { Without } \\
\text { BF }\end{array}$ & $\begin{array}{c}\text { With } \\
\text { BF }\end{array}$ & Mean & $\begin{array}{c}\text { Without } \\
\text { BF }\end{array}$ & $\begin{array}{c}\text { With } \\
\text { BF }\end{array}$ & Mean \\
\hline Control & 25.06 & 45.63 & $35.35 \mathrm{~b}$ & 6.18 & 12.13 & $9.16 \mathrm{~b}$ & 65.56 & 82.36 & $73.96 \mathrm{~b}$ \\
NPK- HLS1 & 72.03 & 76.74 & $74.39 \mathrm{a}$ & 16.59 & 16.91 & $16.75 \mathrm{a}$ & 116.74 & 123.43 & $120.09 \mathrm{a}$ \\
NPK- HLS2 & 73.95 & 76.65 & $75.30 \mathrm{a}$ & 17.30 & 16.41 & $16.86 \mathrm{a}$ & 127.70 & 125.43 & $126.57 \mathrm{a}$ \\
Mean & $57.01 \mathrm{~b}$ & $66.34 \mathrm{a}$ & & $13.36 \mathrm{a}$ & $15.15 \mathrm{a}$ & & $103.33 \mathrm{a}$ & $110.41 \mathrm{a}$ & \\
\hline
\end{tabular}

*BF: basic fertilizer

Means with the same letter are not significantly different

Table 4. Statistical significance and $\mathrm{LSD}_{.05}$ values of the applied treatments on shoot and root dry matter of maize (Zea mays L.) and NPK uptake

\begin{tabular}{|c|c|c|c|c|c|c|}
\hline \multirow{2}{*}{\multicolumn{2}{|c|}{ Treatments }} & \multicolumn{2}{|c|}{ Dry matter } & \multicolumn{3}{|c|}{ Nutrients uptake } \\
\hline & & Shoot & Root & $\mathbf{N}$ & $\mathbf{P}$ & $\mathbf{K}$ \\
\hline Blocks & & $\mathrm{ns}$ & $\mathrm{ns}$ & $*$ & ns & ns \\
\hline \multirow{2}{*}{ NPK- HLS rates } & $\operatorname{LSD}_{.05}$ & $\begin{array}{c}0.230 \\
* * *\end{array}$ & $\begin{array}{c}0.15 \\
\mathrm{~ns}\end{array}$ & $\begin{array}{l}7.97 \\
* * *\end{array}$ & $\begin{array}{c}2.24 \\
* *\end{array}$ & $\begin{array}{c}10.23 \\
* * *\end{array}$ \\
\hline & $\operatorname{LSD}_{.05}$ & 0.37 & 0.18 & 9.76 & 3.71 & 12.53 \\
\hline
\end{tabular}

$*, * *, * * *$ are significant at $0.001,0.01,0.05$ probability level, respectively.

ns: not significant, LSD.05: least significant difference at $5 \%$ 
it had no significant influence on both $\mathrm{P}$ and $\mathrm{K}$ uptake under the two NPK-HLS application rates (Table 4).

\section{CONCLUSION}

The optimum conditions for extraction of humic-like substances from SCG were $2.0 \mathrm{~N} \mathrm{KOH}$ at 1:10 SCG-toextractant ratio, $3 \mathrm{~h}$ reaction time and $80{ }^{\circ} \mathrm{C}$. The adjustment of the $\mathrm{pH}$ of the alkaline K-HLS supernatant at 6.0 by $\mathrm{HNO}_{3}$ and $\mathrm{H}_{3} \mathrm{PO}_{4}$ gave a liquid fertilizer containing 2.0/5.8/8.6 $\left(\mathrm{N} / \mathrm{P}_{2} \mathrm{O}_{5} / \mathrm{K}_{2} \mathrm{O}\right)$ and $5.1 \%(\mathrm{w} / \mathrm{v})$ HLS. Application of this fertilizer enhanced maize growth, NPK uptake, and NPK availability in the tested soil. The proposed method is a new prospective to valorization of such SCG waste material through a short, easy and cheap extraction procedure and the preparation of a liquid mineral-organic fertilizer.

\section{REFERENCES}

Acevedo, F., M. Rubilar, E. Scheuermann, B. Cancino, E. Uquiche, M. Garcés, K. Inostroza, and C. Shene. 2013. Spent Coffee Grounds as a Renewable Source of Bioactive Compounds. J. Biobased Materials and Bioenergy 7: 1-9.

Alves, C. C. O., M. V. Faustino, A. S. Franca, and L. S. Oliveira. 2015. Comparative Evaluation of Activated Carbons Prepared by Thermo-Chemical Activation of Lignocellulosic Residues in Fixed Bed Column Studies. Intern. J. Engin.Technol., 7 (6): 465-469.

Anon, J.L. 2004. Products and trends, New Agric. International, p. 22-34

Asing, J., N.C. Wong and S. Lau. 2009. Optimization of extraction method and characterization of humic acid derived from coals and composts. J. Trop. Agric. and Food Sci. 37(2): 211-223

Ballesteros, L. F., and José A. Teixeira \& Solange I. Mussatto. 2014. Chemical, Functional, and Structural Properties of Spent Coffee Grounds and Coffee Silverskin. Food Bioprocess Technol. 7:3493-3503.

Ballesterosa, L. F., Miguel A. Cerqueiraa, José A. Teixeiraa, Solange I. Mussatto. 2015. Characterization of polysaccharides extracted from spent coffee grounds by alkali pretreatment. Carbohydrate Polymers 127: 347-354.

Bravo, J., I. Ju?niz, C. Monente, B. Caemmererb, L. W. Krohb, M. P. De Pe?a and C. Cid. 2012. Evaluation of spent coffee obtained from the most common coffeemakers as a source of hydrophilic bioactive compounds J. Agric. Food Chem. 60: 12565-12573.

Bremner, J. M. and D. S. Jenkinson. 1960. Determination of organic carbon in soil I. Oxidation by dichromate of organic matter in soil and plant materials. European J. Soil Sci. 11: 394 - 402

Bremner, J. M. and lees, H. 1949. Studies on soil organic matter: II. The extraction of organic matter from soil by neutral reagents. J. Agric. Sci. 39: 274-279.
Campos-Vegaa, R., G. Loarca-Pinaa, H. A. VergaraCastanedac, and B. D. Oomah. 2015. Spent coffee grounds: A review on current research and future prospects. Trends Food Sci. Techno. 45: 24-36.

Canieren, O., Karaguzel, C., and Aydin. A. 2017. Effect of physical pre-enrichment on humic substance recovery from leonardite. Physicochem. Probl. Miner. Process. 53(1): 502-514.

Chapman, H. D., and P. F. Pratt. 1961. Methods and Analysis for Soils, Plants, and Waters. Univ. of Calif., Div. of Agric. Sci. , 309 pp.

Chinmai, K.1 , B. C. Hamsa, K. D. D'souza, B. R. M. Chandra and B. S. Shilpa. 2014. Feasibility Studies on Spent Coffee Grounds Biochar as an Adsorbent for Color Removal International J. Appl. Innovation in Engineer. Manag.. 3(10): 9-13.

Chiyanzy, I., M. Brienzo, M. Garcia-Aparicio, R. Agudelo, and J. Gorgens. 2014. Spent coffee ground mass solubilisation by steam explosion and enzymatic hydrolysis wileyonlinelibrary.com, DOI $10.1002 /$ jctb. 4313

CoHort. 2004. Statistical Analysis Package. CoStat ver 6.303, CoHort Software. Monterey, CA, 93940, USA.

Cruz, R., P. Baptista, S. Cunha, J. A. Pereira, and S. Casal. 2012. Carotenoids of Lettuce (Lactuca sativa L.) Grown on Soil Enriched with Spent Coffee Grounds Molecules 17:1535-1547; doi:10.3390/molecules17021535

Ghabbour, E.A. and G. Davies. 2005. Humic substances: molecular details and applications in land and water conservation. Taylor \& Francis, Inc., New York

Gracia, D., J. Cegarra, M. P. Bernal, and A. Navarro. 1993. Comparative evaluation of methods employing alkali and sodium pyrophosphate to extract humic substances from peat. Comm. Soil Sci. Plant Anal. 24 (13/14): 1481-1494.

Hardgrove, S. J. and S. J. Livesley. 2016. Applying spent coffee grounds directly to urban agriculture soils greatly reduces plant growth. Urban Forestry \& Urban Greening 18: $1-8$.

Hayes, M. H. B. and R. S Swift. 1978. The chemistry of organic matter colloids. In: The Chemistry of Soil Constituents. Greenland, D. J. and Hayes, M. H. B (eds). John Wiley \& Sons. London, UK.

Hoculak-Maczka, M., J. Hoffmann, and K. Hoffmann. 2018. Evaluation of the possibilities of using humic acids obtained from lignite in the production of commercial fertilizers. J. Soils and Sediments. https://doi.org/10.1007/s11368-017-1907-x.

Jutakridsada, P., C. Prajaksud, L. Kuboonya-Aruk, S. Theerakulpisut, and K. Kamwilaisak. 2015. Adsorption characteristics of activated carbon prepared from spent ground coffee. Clean Techn. Environ. Policy. DOI 10.1007/s10098-015-1083-x. 
Kamikuri, N., Y. Hamasuna, D. Tashima, M. Fukuma, S. Kumagai, and J. D. W. Madden. 2014. Low-cost Activated Carbon Materials Produced from Used Coffee Grounds for Electric Double-layer Capacitors. Int. J. Engin. Sci. Innov. Techn. 3 (4): 492-500.

Knany,R.E., R.H. Atia and A.S.M. EL-Saady.2009. Response of faba been to foliar Spraying with humic sabstances and micro nutrients. Alex. Sci. Exch. J.453 - 460.

Kundsen, D., G. A., Peterson, and P. F. Pratt. 1982. Lithium, sodium, and Potassium. In: Methods of Soil Analysis. Part 2, $2^{\text {nd }}$ Edition. Page, A. L., Miller, R. H., and Keeney, D. R. (eds). Madison, Wisconsin, USA.

Morikawa, C.K. and M. Saigusa. 2008. Recycling coffee and tea wastes to increase plant available $\mathrm{Fe}$ in alkaline soils. Plant Soil 304:249-255

Murphy, J. and R. Riley, 1962. A modified single solution method for the determination of phosphate in natural waters. Anal. Chem. Acta. 27: 31-36.

Mussatto, S. I., E. M. S. Machado, S. Martins, and J. A. Teixeira. 2011. Production, composition, and application of coffee and its industrial residues. Food and Bioprocess Techn. 4(5), 661-672.

Namanea, A., A. Mekarziab, K. Benrachedib, N. BelhanecheBensemraa, and A. Hellala. 2005. Determination of the adsorption capacity of activated carbon made from coffee grounds by chemical activation with $\mathrm{ZnCl}_{2}$ and $\mathrm{H}_{3} \mathrm{PO}_{4}$. J. Hazardous Materials 119:189-194.

Olsen, S. R. and L. E. Sommers. 1982. Phosphorus. In: Methods of Soil Analysis. Part 2, $2^{\text {nd }}$ Edition. Page, A. L., Miller, R. H., and Keeney, D. R. (eds). Madison, Wisconsin, USA.

Piccolo, A. 1996. Humus and soil conservation. In: Piccolo A (ed). Humic substances in terrestrial ecosystems. Pp 225264. Elsevier, Amsterdam.

Pujol, D., C. Liu, J. Gominho, M. A. Olivella, N. Fiol, I. Villaescusa, and H. Pereira. 2013. The chemical composition of exhausted coffee waste. Industrial Crops and Products. 50: 423-429.
Punnett, P.W. 1958. Spent grounds cause major soluble problem. Tea Coffee Trade J. 114:41-42.

Saito. B. and M. Seckler. 2014. Alkaline extraction of humic substances from peat applied to organic-mineral fertilizer production. Brazilian J. Chem. Eng. 31: (3) 675-682.

Schnitzer, M. 1982. Organic matter characterization. In: Methods of Soil Analysis. Part 2, $2^{\text {nd }}$ Edition. Page, A. L., Miller, R. H., and Keeney, D. R. (eds). Madison, Wisconsin, USA.

Silva, M.A., S.A. Nebra, M.J.M. Silva, and C.G. Sanchez. 1998. The use of biomass residues in the Brazilian soluble coffee industry. Biomass Bioenergy 14:457-467.

Stevenson, F.J. 1982. Humus Chemistry. New York: John Wiley \& Sons

Stevenson, F.J. 1994. Humus Chemistry. Genesis, composition, reactions, p. 26-52. New York: John Wiley $\&$ Sons

Suarez-Estrella, F., M. C. Vargas-Garcia, M. J. Lopez, and J. Moreno. 2008. Effect of humic substances extracted from compost to plant growth and soil microorganisms. Dyn. Soil, Dyn. Plant. 1: 96-102.

Swift, R.S. 1996 Organic matter characterization (chap 35). pp. 1018-1020. In D.L. Sparks et al. (eds). Methods of soil analysis. Part 3. Chemical methods. Soil Sci. Soc. Am. Book Series: 5. Soil Sci. Soc. Am. Madison, WI

USDA. 2016. Coffee: World Markets and Trade. Foreign Agricultural Service, United States Department of Agriculture.

Valdrighi, M. M., A. Pera, M., Agnolucci, S., Frassinetti, D., Lunardi, and G. Vallini. 1996. Effect of compostedderived humic acids on vegetable biomass production and microbial growth within a plant (Chichrium intybus)-soil system: A comparative study. Agric. Ecosyst. Environ. 58: 133-144.

Yamamoto, S., T. Honna, N. Sanatani, and K. Llmura, 1994. Influence of extracting temperature on diluted sodium hydroxide soluble humus properties. 2: Determination of humus extracts caused by the heating extraction in boiling water. Pedologist. 38(2): p.3. 


\section{الملخص العربي}

سماد NPK سائل يحتوى على مو اد شبه دبالية مستخلصة من تفــلة القهوة: الإستخلاص، التحضير،

\section{وتأثيره على نبات الأرة}

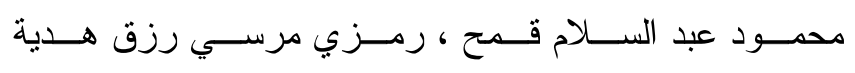

ذو لون بني غامق بحتوي علــى العناصــر (NPK-HLS)

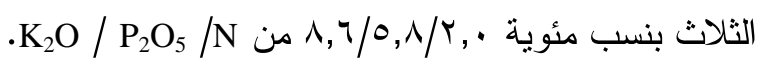
وقد تم تقييم استخدام مستحضر السماد لنمو نبات الــذرة في تربة جيرية عن طريق إجراء تجربة أصــص باتبــاع

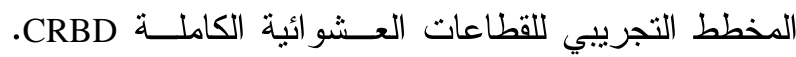
حيث ثم إضافة معدلين من مستحضر السماد NPK-HLS1)

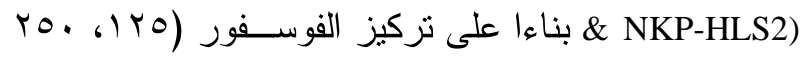
مجم P لكل أصيص) في وجود أو عدم وجود سماد بــادئ و الذى أضيف قبل الزر اعة. وقد (BF: KAP and $\mathrm{NH}_{4} \mathrm{NO}_{3}$ ) وجد أن معدل الإضافة NPK-HLS1 أدى إلى زيادة معنوية في المادة الجافة، وكذلك الكمية الممتصة من العناصر NPK بو اسطة نبات الذرة. ولم يوجد أي تأثير معنوي لإضـــافة السماد البادئ BF فى وجود سماد NPK-HLS تحت ظروف التجربة على هذه المتغيرات. ولم ثؤدي زيادة معدل إضافة مستحضر السماد إلى NPK-HLS2 إلى أي زيادة معنوية في نفس المتغيرات المقاسة. كما وجد أن هناك زيادة معنوية في الصور المتاحة من عناصر NPK المتبقية في التربـــة بعـــ الحصاد، وقد وجد أن ذلك يرجع الى تأثز معامات السماد البادئ ومستحضر السماد منفردين أومجتمعين معا. هــذا، ويمكن اعتبار مستحــضر الـسماد NPK-HLS باسـتخدام المستخلص القلوي لتفلة القهوة حلا بديلا لمشكلة تر اكم تفلة القهوة.
تعتبر إعادة استخدام المخلفات الزر اعية مــن الحلــول الذكية لتقليل الأثر البيئي وزيادة القيمة الإقتصادية المضافة

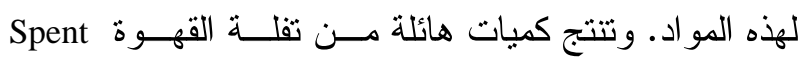
Coffee Grounds (SCG) الاستخلاص) على مستوى العالم. وعليه، كانت أهداف هذه الدر اسة هى إيجاد أفضل الطرق لاستخلاص المواد شــبيهة الدبال Humic-like Substances (HLS) مــن تقلــة القهــوة باستخدام محلول استخلاص قلوي مـن KOH، وتحــير سماد معدني-عــضـوي بإضــافة عنــصري النيتــروجين و الفوسفور ، وكذلك در اسة تأثير إضـافة السماد علــى نـــو نبات الذرة (Zea mays L).وقد أوضحت النتائج أن نسسبة استخلاص المواد شبه الدبالية من تقلة القهوة قد إزدادت مع زيادة تركيز محلول KOH حتى تركيز ب عيارى ومع نسبة تقلة القهوة الى محلول الإستخلاص حتى ا: . 1 وذلك عنـــ

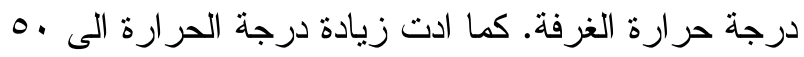

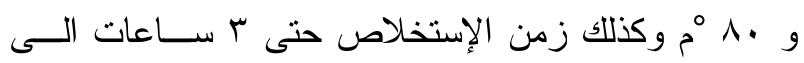
زيادة نسبة الإستخلاص. وقد اوضحت الدراسة أن الظروف

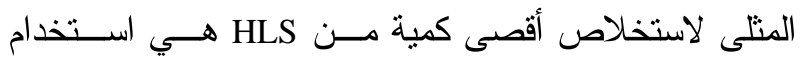
تركيز r عيارى من محلول KOH، عند نسبة تقلة القهــوة: المحلول ا: • 1 ، وزمن تفاعل ب ساعات، وعنــد درجــة

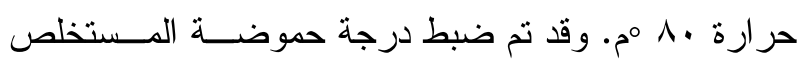
الناتج، و الوصول إلى 6 pH باستخدام خليط مــن حمــ النيتريك و الفوسفوريك. وقد كان مستحضر الــسماد النــاتج 